\title{
A literature review of the impact of HIV and AIDS on the role of the elderly in the sub-Saharan African community
}

Author:
Eucebious Lekalakala-
Mokgele $^{1}$
Affiliation:
'School of Health Care
Sciences, University of
Limpopo (Medunsa Campus),
South Africa
Correspondence to:
Eucebious Lekalakala-
Mokgele
Email:
sebi.lekalakala-mokgele@
ul.ac.za
Postal address:
PO Box 72, Medunsa 0204,
South Africa
Dates:
Received: 04 June 2010
Accepted: 29 Aug. 2011
Published: 10 Nov. 2011
How to cite this article:
Lekalakala-Mokgele,E.,
2011, 'A literature review
of the impact of HIV and
AIDS on the role of the
elderly in the sub-Saharan
African Community', Health
SA Gesondheid 16(1), Art.
\#564, 6 pages. http://dx.doi.
org/10.4102/hsag.v16i1.564

C 2011. The Authors. Licensee: AOSIS OpenJournals. This work is licensed under the Creative Commons Attribution License.
The status of older adults in Africa occupies a small but rapidly expanding share of the global literature on ageing. The human immunodeficiency virus (HIV) and acquired immune deficiency syndrome (AIDS) pandemic has generated a new focus on the changing role of the elderly in communities that have been affected. In sub-Saharan Africa, where millions are projected to be infected with HIV and about two million deaths are recorded annually amongst the traditionally productive adults, such loss of parents and breadwinners means children and the elderly have had to take up unusual responsibilities. A literature review on the elderly and HIV and AIDS provided the data analysed for this article. Access to databases was mainly via EBSCO (www.ebsco.co), which allowed searches in major databases and search engines useful in an academic setting for finding and accessing articles in health and health-related academic journals, repositories and archived reports.

Results showed that the AIDS pandemic has direct and indirect effects which have manifested in a set of interrelated social, economic and psychological dimensions that could ultimately impact on the health and well-being of the elderly. It is concluded that more needs to be done to articulate the knowledge base of the impact of HIV and AIDS in order to inform social, economic and political policies for the purpose of alleviating the problems that the pandemic is wreaking on the elderly African population.

Die status van ouer volwassenes in Afrika beklee'n klein, maar vinnig groeiende deel van die globale verouderings literatuur. Die menslike immuniteitsgebreksvirus (MIV) en verworwe immuniteitsgebreksindroom (VIGS) pandemie het 'n nuwe fokus op die veranderende rol van bejaardes in die gemeenskap wat deur VIGS beïnvloed word, gegenereer. In sub-Sahara Afrika waar na beraming miljoene geïnfekteer word met MIV, met sowat twee miljoen sterftes jaarliks gerekordeer onder die tradisoneel produktiewe volwassenes, word daar van die kinders en bejaardes verwag om ongewone verantwoordelikhede op hulle te neem as gevolg van die verlies aan ouers of broodwinners. 'n Literatuuroorsig wat handel oor bejaardes en MIV en VIGS het die geanaliseerde data voorsien vir hierdie artikel. Toegang tot die databasis was meestal deur EBSCO (www.ebsco.co) wat soektog toegelaat het tot groot databasisse en soekenjins wat bruikbaar in die akademiese opset is en die vind van artikels aangaande gesondheid, gesondheidverwante akademiese joernale en argief verslae. Bevindings toon dat die VIGS pandemie direkte en indirekte effekte het. Hierdie effekte manifisteer in ' $n$ stel sosiaal verwante, ekonomiese en psigologiese dimensies wat ten einde ' $n$ impak op die gesondheid en welstand van bejaardes het. Daar is tot die gevolgtrekking gekom dat meer gedoen moet word om die kennis basis van MIV en VIGS te artikuleer om die sosiale, ekonomiese en politiese beleid in kennis te stel, om sodoende die resulterende probleme van MIV en VIGS op die bejaarde Afrika populasie te verlig.

\section{Introduction and background}

The elderly population in Africa above 60 years in age is currently estimated to number slightly over 38 million, and is projected to reach between 203 and 212 million by 2050 (HelpAge International 2002). Over the last decade the human immunodeficiency virus (HIV) and acquired immune deficiency syndrome (AIDS) epidemic has had a devastating impact on older women and men, especially in sub-Saharan Africa; with about two million deaths recorded annually and at least 13 million children have lost one or both parents (Alpaslan \& Mabutho 2005:276). The rapid growth of population ageing in Africa and the impact of HIV and AIDS add another dimension to the role of older persons. HIV and AIDS affects older people in two main ways: the elderly are themselves infected with HIV, making them vulnerable to many health and socio-economic 
challenges (Waysdorf 2002:51; Ramos Rodriguez, Baney, Morales, Parham \& Lago 2000:13), and it places a burden on them as carers since many have to care for their sick children and are often left to look after orphaned grandchildren who are also infected (Rajaraman, Earleb \& Heymann 2008:2; Lalthapersad-Pillay 2008:151; Van Dullemen 2006:101). The extended family used to be relied upon to provide subsistence and care for older persons.

The issue of the HIV and AIDS pandemic has generated a new focus on the changing role of the elderly in communities affected by AIDS. An estimated 22 million adults and children were living with HIV in sub-Saharan Africa at the end of 2007, and during that year an estimated 1.5 million Africans died from AIDS. The epidemic has left behind some 11.6 million orphaned African children (AVERT 2009). HIV and AIDS have resulted in a reversal of roles, where older persons are now providing subsistence and care to younger generations (Makiwane, Schneider \& Gopane 2004:12; Kimuna \& Makiwane 2007:97). The African extended family has traditionally nursed its sick and absorbed its orphans without legal process (Alpaslan \& Mabuthu 2005: 276). Many governments and major international donors have therefore reacted to growing evidence of the impact of HIV and AIDS on households by suggesting that 'traditional' coping mechanisms would minimise the impact and allow households and communities to absorb the loss of members (Economic Commission for Africa 2009). However, this is yet to be demonstrated, since there is growing evidence of multiple crises faced by those families now being headed by the elderly in Africa (Makiwane et al. 2004:9).

Many countries in sub-Saharan Africa have adopted the primary health care (PHC) approach, one of its worthy goals being provision of basic care for the elderly (Brathwaite et al. 2002:4). However, PHC does not address the specific needs of the elderly since most nurses working in this setting are not specifically trained to work with them. Care for the older person is not a priority in many countries, and most nursing schools and colleges do not offer courses in gerontology and geriatric care. For example, the National Qualification Framework of the South African Nursing Council excludes courses in gerontological nursing science or gerontology (including geriatrics). Also, ageist and sexist stereotypes perpetuate the myth that the elderly are asexual (Spearman \& Bolden 2005:53), evident in the fact that PHC providers do not ask the elderly specific question related to assessing risk behaviours for HIV and AIDS.

Whilst the global community is preoccupied with combating the HIV and AIDS pandemic, particularly amongst the middle-age group, there appears to be an under-reporting of its impact on the lives of the elderly (Makiwane et al. 2004:11; HelpAge International 2007). It is important to document the impact of HIV and AIDS on the elderly, particularly within the sub-Saharan African community where the burden of caring for the sick has shifted onto the shoulders of the elderly left in the community.
The aim of this research is to review studies on the impact of HIV and AIDS on the elderly in sub-Saharan African communities, and to provide systematic documentation of the challenges and impact of HIV and AIDS on the elderly as reported in contemporary literature. The following questions are addressed: What are the challenges faced by the elderly as a result of HIV and AIDS in the African community; and how do HIV and AIDS impact on the role of the elderly in sub-Saharan African communities?

\section{Methods}

A literature search on the impact of HIV and AIDS on the elderly in sub-Saharan Africa was carried out in April 2009 by means of a multiple electronic database search using the combined keywords of elderly, older person, HIV and AIDS, and socio-economic impact. An additional manual search was done to obtain published works identified through the electronic search. The search was limited to studies conducted in sub-Saharan Africa and in academic literature referring to the elderly and HIV and AIDS in sub-Saharan Africa, as well as reports written by organisations that support the cause of the elderly. Access to the databases was mainly via a Cumulative Index of Nursing and Allied Health and Health Literature (CINAHL) and Pre-CINAHL, Academic Search Premier, Cochrane Library, Academic, MasterFILE Premier Africa-Wide:NiPAD, and NEXUS database system (http:/ / stardata.nrf.ac.za/) that provides access to completed and current research projects in South Africa, and Science Direct.

The review included full-text articles, abstracts and reports, as well as academic theses published by various specialists. A total of 82 documents ( 68 articles, 4 theses and 10 reports) referring to the impact of HIV and AIDS on the elderly was reviewed. Studies were included if they met the following criteria: conducted in sub-Saharan Africa; HIV was the impacting factor; and they included older persons or elderly persons aged 60 years and older. Each item was examined for the purpose of describing and summarising the body of literature available on this area, read and grouped according to themes, as reported below.

\section{Results}

Results regarding the impact of HIV and AIDS on the elderly were analysed and grouped according to the following themes: impact on the health of the elderly; social impact; economic impact; and psychological impact. Each of these themes is further unpacked below.

\section{Impact of HIV and AIDS on the health of the elderly}

Evidence suggests that HIV infection amongst the older population is on the increase, with more than $10 \%$ of HIV infection found amongst older adults (Manfredi 2004:33; Ramos Rodriguez et al. 2000:13; Inelmen, Gasparini \& Enzi 2005:26; HelpAge International 2008). The increase of AIDS in the elderly population suggests that they engage in activities that are risky for HIV infection (Cintron-Bou 2004). Reports 
on such behaviour amongst the elderly include frequent sexual relations with much younger people and reluctance to use condoms (Andoulo, Meku \& Léon 2004), being less concerned about being infected (Silva et al. 2002), ignorance (Msobi, Fimbo \& Msumi 2004), and having multiple partners (Ramos Rodriguez et al. 2000). According to Ramos Rodriguez et al. (2000), health care providers are not assessing the risk of HIV infection in this population. Many doctors incorrectly diagnose early AIDS symptoms in the elderly as pre-senility, because they do not suspect HIV in their older patients and miss the opportunity for testing (Inelmen et al. 2005:26).

A review conducted by Holmgren, Aaby, Jensen, Larsen, Da Silva and Lisse (1999:460) suggests that women in subSaharan Africa of over 55 years of age have a seven times higher risk of sero-converting compared to people of a younger age, including men. Reports show that the severity of HIV and AIDS symptoms is more pronounced in the elderly population, leading to a poorer prognosis (Butt, Dascomb, DeSalvo, Bazzano, Kissinger \& Szerlip 2001:394; Breux et al. 1996). Kipp, Tindeyebwa, Rubaale, Karamagi and Banjenja (2007:867) and the Economic Commission for Africa (2009) report that the health of older care-givers has deteriorated as a result of the physical and emotional stress of assisting their children. The physical impact of caring for the ill, such as backache, chest and leg pains, was attributed to the frequent changing, lifting and washing of adult patients (Ssengonzi 2007:349).

In summary, HIV infection amongst the elderly population is on the increase. The elderly do not have the benefit of early diagnosis due to myths about their sexual activities. They are also outside the target populations for HIV prevention programmes.

\section{Social impact}

Studies show that HIV and AIDS attack mostly the reproductive and economically active section of the population, changing family composition by decimating the young adult population and creating elderly femaleheaded and child-headed families (Makiwane et al. 2004: 9; Ainsworth \& Dayton 2003:131; Bohman, Vasuthevan, Van Wyk \& Ekman 2007:335; AVERT 2009; Drimie 2002:654; Schatz \& Ogunmefun 2007:1391; Alpaslan \& Mabutho 2005:276). The traditional support system for the elderly is hereby destabilised (Schatz 2007).

In sub-Saharan Africa alone millions of children grow up without parents and often live with grandparents (UNAIDS \& UNICEF 2004). A review of the composition of households consisting of older adults in 24 countries of sub-Saharan Africa showed that $59 \%$ live with children and $46 \%$ with a grandchild, and that older adults are more likely to be living with double orphans (where both parent have died) in countries with high AIDS-related mortality (Zimmer \& Dayton 2005: 297). Reviews show that elderly-headed families cannot cope with the increasing number of orphans created by the disease (AVERT 2009; Cohen 1998). Social networks are reported to have collapsed due to the pressure of having to support orphaned children (Halkett, 2000, in Aliber 2001; Cohen 1998). Intra-familial relations become strained if conflict over custody arises or grandparents judge other family members to be negligent of the grandchildren (Alspaslan \& Mabutho 2005:277). The roles of the elderly are seen to be changing to being care-givers of their adult children stricken with HIV and AIDS, guardians of their orphaned grandchildren, and surrogate parents for these grandchildren (Ainsworth \& Dayton 2003:132; Fouad 2004; HelpAge International 2007; Bock \& Johnson 2008:1; Nel 2004), which results in an increased burden of caring resting on the elderly.

Increased social responsibility of the elderly is reported, due to prolonged travelling and absence from their homes to care for sick and orphaned grandchildren (Ssenengozi 2009; Schatz 2007:151). This increase results in social isolation, because the elderly cannot afford the time or money to take part in social activities (HelpAge International 2008). Another reason for reducing participation in social activities is fear of stigmatisation, as reported by Alpaslan and Mabutho (2005:277).

Food insecurity is found to be prevalent in elderly households, and the care-giving responsibilities exacerbate the already compromised nutritional status of the elderly (Charlton \& Rose 2001:2424; Nyanguru 2003:173; Mba, Addico \& Adanu 2007:61).

\section{Economic impact}

The literature reveals that many persons affected by HIV and AIDS in sub-Saharan Africa remain at home, with the main burden of their care resting almost entirely on family members, who in most cases are elderly females (Kipp et al. 2007:857; Schatz \& Ogunmefun 2007:1392; Bock \& Johnson 2008; Baylies 2002; Nel 2004; Ogunmefun \& Schatz 2009). The literature also shows that whilst the economic consequences for the elderly who give care to the sick and orphans or have lost children to HIV and AIDS cannot be quantified, their impact is great.

The care-giving role of the elderly is such that it overwhelms their livelihood, forcing them to contend with various demands in terms of coping with increased health care costs, including debts incurred as a result of HIV and AIDS-related illnesses (HelpAge International 2003; Ssengonzi 2007:349; Okayo 2004) and meeting the transport and medical costs of ailing children (May 2003; Ssengonzi 2007:349), paying school fees for orphaned grandchildren (HelpAge International 2003; Nel 2004), and paying the funeral expenses of their family members (Kipp et al. 2007:859; Schatz \& Ogunmefun 2007:1392; Bock \& Johnson 2008; Baylies 2002; Nel 2004; Fouad 2004). They also have to meet the costs of grandchildren (some of whom may be HIV positive) for whom they must now provide care (HelpAge International 2003; Ssengonzi 2007:249; Okayo 2004). 
Extended family members are not in a position to assist elderly care-givers (Alpaslan \& Mabutho 2007:277) due to harsh economic conditions (Kaseke \& Gumbo 2001:54). Worst of all, the grandmothers are left without any inheritance from the deceased parents of AIDS orphans (Alpaslan \& Mabutho 2007:287). The elderly are seen as being financially abused (Makiwane et al. 2004:12).

The literature shows that the economic impact of HIV and AIDS on the elderly is overwhelming to them, and they seem to have no financial support. The least economically productive in society - the elderly - bear the financial burden of caring for the sick relatives and orphaned grandchildren left behind.

\section{Psychological impact}

The literature review on HIV and AIDS revealed various psychological impacts on the elderly. For those that are infected, experiences of hopelessness and loneliness, shame and fear of being infected are documented (Landman 2008:57). Because of the myth that the elderly are asexual, infected elderly women feel humiliated by their sexuality and their own fear bars them from seeking health care and support since they fear stigmatisation (Otani 2004; Mlobeli 2007).

Reports on caring activities show that the elderly worry about the impending death of adult children as well as the emotional stress of nursing terminally ill relatives and being infected during the process of caring (Alpaslan \& Mabutho 2005:277; May 2003:18-19; Lalthapersad-Pillay 2008:153; Otani 2004; HelpAge International 2003; Ssengonzi 2007:342). When the children eventually die, grandparents endure the trauma of the loss of family members and have to cope with the stigma associated with HIV and AIDS (HelpAge International 2003), even long after the death of their children. Caring for grandchildren is also burdensome, since orphans often refuse to accept the authority of the older persons and the elderly experience problems in disciplining them (Barnett \& Blaikie 1992:119; Alpaslan \& Mabutho 2005:277).

In certain instances the elderly reduce participation in social activities, since they fear negative community reactions towards the HIV-positive grandchildren in their foster care. This is compounded by concerns over grieving children who must also cope with the community stigma attached to and often irrational fear surrounding AIDS (Alpaslan \& Mabutho 2005: 277). In general, worsening psychological health of the elderly has been reported (Oburu \& Palmérus 2003:505).

In summary, HIV and AIDS have a negative psychological impact on the well-being of the elderly who are either infected or affected by this pandemic. This negative impact manifests in many forms, including fear, trauma and grieving, isolation, hopelessness and stigmatisation.

\section{Recommendations Recommendations for the elderly}

Empowerment of the elderly is imperative so that they can address their own needs without fear of stigmatisation. Empowerment starts with educating the elderly about HIV, its mode of transmission, strategies to prevent infection, and to make them aware of their rights as citizens. HIV and AIDS prevention programmes should be user-friendly, appealing to the level of maturity of the elderly. The programme should adopt cultural aspects that promote health which the elderly have used throughout their lives. The elderly in most African countries are seen as the pillar of morality; this should be used as a foundation of developing programmes for them. Ageappropriate advertising should be considered to increase acceptability of HIV and AIDS prevention programmes by the elderly.

\section{Recommendations for communities}

The practice that excludes the elderly from developmental programmes, including HIV and AIDS prevention programmes, needs to be abandoned. The education of communities should focus on the needs of the elderly and raising awareness on issues of ageism and challenging stigma at local level, including in churches and the community. Community networks for the elderly, targeting those caring for the sick at home, should be made a priority. Capacity building of the elderly to cope with HIV and AIDS issues at community level should be prioritised. Government structures tasked with ensuring the well-being of the elderly should actively conduct workshops in communities to inform the elderly about services available to them, since most do not have knowledge of these. Educational programmes (similar to those in South Africa) should be designed to enable the elderly to read and write, as this will facilitate their understanding of written material.

Nurses in the PHC setting should include health education for the elderly specifically targeting HIV prevention. Community nurses should promote support groups for affected families. Churches and traditional services should form the basis of emotional and psychological support for the elderly, as spirituality and religion play an essential role in health and healing and offer hope in the midst of life challenges. Homebased care for the elderly and infected family member or members should be developed. Multi-sectorial collaboration and mobilisation of communities, including people living with HIV and AIDS, are vital for sustainable solutions.

\section{Recommendations for health care providers}

Gerontology and geriatric care should form an integral part of PHC. The lack of such care can extrapolate further to lack of assessment of HIV infection in the elderly population in the PHC setting by nurses. For the purpose of early diagnosis health care providers, particularly at PHC level, should be trained to screen women of all ages for HIV infection. They should discuss known risk factors with the elderly and 
ask about behaviours that place them at risk. Stereotypical stances among nurses that the elderly are asexual should be brought to their attention so that they can be dispelled. In addition, health care providers must identify and implement prevention strategies tailored for the elderly. This can be done by promoting peer-led support groups that enable the elderly to communicate their sexual activities freely.

\section{Recommendation for governments}

Governments and all stakeholders should implement policies and strategies that will provide sufficient physical, emotional and financial support for the elderly to be able to care for their orphaned grandchildren and themselves. These should value older people's societal contributions and increase their social standing.

Promotion of public recognition of the value of the elderly should form the basis of policies for older persons. Programmes that build on the roles of older women within the context of African society in the bid to reduce HIV transmission should be used. Culturally safe peer education programmes for AIDS prevention amongst older women should be supported.

Government should support training programmes for older carers in home-based care to improve their knowledge of best practices of care for the sick, and to ensure the supply of essential equipment for caring for their sick relatives. The elderly should be educated about HIV transmission and prevention strategies so that they can inform the younger grandchildren they care for and protect themselves during their caring.

Income-generating projects for the elderly should be organised to make up for the deficit caused by caring, such as needlework, baking, beading and selling of products. African grandmothers have always taken care of their grandchildren, long before the HIV and AIDS pandemic infiltrated the continent. Communities can make use of the natural caring skills of grandmothers by assigning children to their care and remunerating them for this service. Finally, governments should formalise the system of foster-care placements of orphans and support the elderly financially in their caring for these orphans.

\section{Conclusion}

HIV impacts on the elderly in two main ways: first, about $10 \%$ of the elderly are themselves infected with HIV, leading to their early death; and second, HIV and AIDS affect older persons as parents and/or relatives of persons infected by HIV and as care-givers. These indirect effects can manifest in a set of interrelated social, economic and psychological dimensions that could ultimately impact on the health and well-being of the elderly.

Many elderly persons are shouldering vital caring responsibilities for loved ones living with HIV and grandchildren orphaned by AIDS, which is a common practice in most African communities. Child fosterage is not a new phenomenon in Africa, as grandparents and other elderly relatives have traditionally played a key role here, albeit in different forms across the continent. However, child fostering as a result of HIV and AIDS is crisis-led, since the older person has to meet the daily costs of living as well as funding their grandchildren's education without support from Government or their own children since most have been decimated by AIDS.

The cost of the illness for ailing HIV-infected persons drains the limited resources that elderly care-givers might have. The social impact of HIV and AIDS has in some cases led to loneliness, isolation and stigma in the lives of the elderly. In many instances the elderly, who are close relatives of HIV-infected persons, are depressed because of the looming death of a loved one in their midst. In the case of the elderly relatives, especially when they are the parents, this emotional toll could influence their ageing process, coming as it does at a stage in their lives when they are progressing to frailty.

The absence of national policies on ageing in many African countries exacerbates the poverty, poor health and psychological stress experienced by the elderly who are affected by HIV and AIDS. It is based on the above impacts found in the literature that the above recommendations are suggested for the elderly, the community, and Government.

\section{Acknowledgements Competing interests}

The author declare that she have no financial or personal relationship(s) which may have inappropriately influenced her in writing this paper.

\section{References}

AVERT, 2009, AIDS Orphans, viewed 20 February 2009, from Http://www.Avert.Org/ Aidsorphans. Html. Updated 20 February 2009

Ainsworth, M. \& Dayton, J., 2003, 'The impact of the aids epidemic on the health of older persons in North-Western Tanzania', World Development 31(1), 131-148. http://dx.doi.org/10.1016/S0305-750X(02)00150-X

Aliber, M., 2001, 'Study of the incidence and nature of chronic poverty and development policy in South Africa: an overview', Background Paper 3, Chronic Poverty Research Centre, University of Western Cape, Cape Town.

Alpaslan, A.H. \& Mabutho, S.L., 2005, 'Caring for AIDS orphans: The experiences of elderly grandmother caregivers and AIDS orphans', Social Works 41(3), 276-295.

Andoulo, R.D., Meku, R. \& Léon, M.I., 2004, 'The elderly and the prevention of HIV transmission: the case of centres for prevention and voluntary testing (CPVT) in Yaounde, Cameroon', paper presented at the 15th International conference on AIDS, Bangkok, Thailand, 11-16th July.

Barnett, T \& Blaikie, P., 1992, AIDS in Africa: Its present and future impact, Belhaven Press, London.

Brathwaite, D., Mogotlane, S., Rodrigues, H., Dorsey, S., Mangongo, R. \& Matlakala, M., 2002, 'Elderly citizen's perception of their health and care provided in a rural South African community', ABFN Journal, March-April, viewed 23 April 2009, from findarticles.com/p/articles/mi_m0MJT/is_2.../ai_93610977/

Baylies, C., 2002, 'HIV/AIDS and older women in Zambia, Concern for self, worry over daughter, tower of strength', Third-World Quarterly, 23(2), 351-375. http:// dx.doi.org/10.1080/01436590220126685

Bock, J. \& Johnson, S., 2008, 'Grandmothers' productivity and the HIV/AIDS pandemic in sub-Sahara Africa', Journal of Cross-Cultural Gerontology 23(1), 1-25. PMid:17957462

Bohman, D.M., Vauthevan, S., Van Wyk, N.C. \& Ekman, S., 2007, 'We clean our houses, prepare for weddings and go to funerals: Daily lives of elderly Africans in Majaneng, South Africa', Journal of Cross Cultural Gerontology 22, 323-337. http://dx.doi.org/10.1080/01436590220126685, PMid:17616794 
Breux, J.P., Venot, C., Daynac-Roy, F., Descamps, J.M., Boiffard, O., Bonneyfoy, C. Collin, B., Agius, G. \& Becq-Giraudon, B., 1996, 'HIV infection in the elderly: later diagnosis, poorer prognosis' (abstract No.I 128), Interscience Conference on diagnosis, poorer prognosis' (abstract No. 128), Interscience Conference on

Butt, A.A., Dascomb, K.K., Desalvo, K.B., Bazzano, L., Kissinger, P.J. \& Szerlip, H.H., 2001, Human immunodeficiency virus infection in elderly patients, South African Medical Journal, 94, 394-400.

Charton, K.E. \& Rose, D., 2001, 'Nutrition among the older adults in Africa: the situation at the beginning of the millennium', Journal of Nutrition 131 (Suppl), s2424-s2428.

Cintron-Bou, F., 2004, 'Old enough to get AIDS? Sure you are: HIV/AIDS among the elderly of Purto Rico', 15th International Conference on AIDS, Bangkok, Thailand, 11-16th July.

Cohen, D., 1998, Poverty and HIV/AIDS in sub-Saharan Africa, United Nations Development Programme Issue Paper No 27. UNDP.

Drimie, S., 2002, The impact of HIV/AIDS on rural households and land issues in Southern and Eastern Africa, background paper prepared for the Food and Agricultural Organization, Sub-regional Office for Southern and Eastern Africa, Human Sciences Research Council, Pretoria, pp. 648-658.

Economic Commission for Africa, 2009, The impact of HIV/AIDS on families and communities in Africa, viewed 26 June 2009, from

Fouad, D., 2004, Role of elderly people in the era of HIV/AIDS in Africa, paper presented at the African Conference on Ageing, Johannesburg, South Africa, viewed 24 June 2009 from Http:www.Globalageing.Org/Armedconflict/Countryreports/General/ Old\%20HIV.

HelpAge International, 2002, Leading global action on ageing, Gender and ageing briefs, HelpAge International, London.

HelpAge International, 2003, Forgotten Families: Older people as carers of orphan and vulnerable children, HelpAge International, London.

HelpAge International, 2007, Stronger Together, HelpAge International, London.

HelpAge International, 2008, 'Older people invisible in international AIDS Response', viewed July 25, 2009, from http://www.helpage.org.

Holmgren, B., Aaby,P., Jensen, H., Larsen, O., Da Silva, Z. \& Lisse, I.D., 1999, Increased prevalence of retrovirus infections among older women in Africa, Scandinavian Journal of Infectious Diseases 31, 459-466. PMid:10576124

Inelmen, E.M., Gasparini, G. \& Enzi, G., 2005, 'HIV/AIDS in older adults. A case report and literature review', Geriatrics 60 (9), 26-30.

Kaseke, E. \& Gumbo, P., 2001, 'The AIDS crisis and orphan care in Zimbabwe', Social Work 37(1), 53-58.

Kimuna, S.R. \& Makiwane, M. 2007, 'Older people as resources in South Africa: Mpumalanga households', Journal of Aging \& Social Policy 19(1): 97-114. http:// dx.doi.org/10.1300/J031v19n01_06

Kipp, W., Tindeyebwa, D., Rubaale,T., Karamagi, E. \& Banjenja, E., 2007, 'Caregivers in rural Uganda: The hidden reality', Health Care for Women International 28, in rural Uganda: The hidden reality', Health Care for Women International

Lalthapersad-Pillay, P., 2008, 'The orphans problem in selected African countries', Africa Insight 37(4), 148-159.

Landman, C., 2008, A theology for the older female HIV- infected body, Exchange 37 52-67. http://dx.doi.org/10.1163/157254308X251340

Makiwane, M., Schneider, M. \& Gopane, M., 2004, Experiences and needs of older persons in Mpumalanga, Human Sciences Research Council, Pretoria.

Manfredi, R., 2004, 'HIV disease and advanced age. Emerging epidemiological, clinical and management issues', Ageing Research Reviews 3, 31-54. http://dx.doi. org/10.1016/j.arr.2003.07.001. PMid:15164725

May, A., 2003, Social and economic impacts of HIV/AIDS in Sub-Sahara Africa with specific reference to aging, Institute of Behavioural Science, Population Aging Centre, University of Colorado, Boulder.

Mba, C., Addico, G. \& Adanu, R., 2007, 'An in-depth analysis of socio-demographics living arrangements and health conditions of Ghana older population', Research Review 2007, 61-70.
Mlobeli, R., 2007, 'HIV/AIDS Stigma: An investigation into the perspectives and experiences of people living with HIV/AIDS', Masters Dissertation, Dept of Psychology, University of Western Cape.

Msobi, N.D., Fimbo, B. \& Msumi, Z., 2004, 'AIDS among elderly people in the rural community, Lake Zone, Tanzania', 15th International Conference on AIDS, Bangkok, Thailand, 11-16th July.

Nel, S., 2004, 'The impact of South African social welfare policies on pensioners raising orphaned grandchildren', Masters Dissertation, School of Public Management \& Planning, Stellenbosch University.

Nyanguru, A.C., 2003, 'Income support and the promotion of the rights of the elderly in Lesotho', The African Anthropologist 10(2), 154-179.

Oburu, P.D. \& Palmérus, K., 2003. 'Parenting stress and self-reported discipline strategies of Kenyan caregiving grandmothers', International Journal of Behaviora Development 27(6), 505-512. http://dx.doi.org/10.1080/01650250344000127

Ogunmefun, C. \& Schatz, E., 2009, 'Caregiver's Sacrifices: The opportunity costs of adult morbidity and mortality for female pensioners in rural South Africa', Development Southern Africa 26 (1), 95-109. http://dx.doi.org/10.1080/03768350802640123

Okayo, J. A., 2004. 'The plight of the elderly as care-givers to people affected/infected by HIV/AIDS', 15th International Conference on AIDS, Bangkok, Thailand, 11-16th July.

Otani, J., 2004, 'HIV/AIDS and older people', 15th International Conference on AIDS, Bangkok, Thailand, 11-16th July.

Rajaraman, D., Earleb, A. \& Heymann, S. J., 2008, 'Working HIV care-givers in Botswana: Spill-over effects on work and family well-being', Community, Work \& Family 11(1), 1-17. http://dx.doi.org/10.1080/13668800701785296, PMid:2576907

Ramos Rodriguez, C., Baney, M., Morales, R.J., Parham., D. \& Lago, M., 2000 International Conference on AIDS, New York, United States of America, 9th, 13-14th July.

Schatz, E.J., 2007, "'Taking care of my own blood". Older women's relationships with their households in rural South Africa', Scandinavian Journal of Public Health 35 (Suppl 69), 147-154.http://dx.doi. org/10.1080/14034950701355676, PMid:17676516, PMCid:2830102

Schatz, E. \& Ogunmefun, C., 2007, 'Caring and contributing: The role of the older women in rural South African multigenerational households in the HIV/AIDS era', World Development 35(8), 1390-1403. http://dx.doi.org/10.1016/j. worlddev.2007.04.004

Silva, M., Fontenelle, D.S., Cabral, S.F., Maganha, M.E., Nascimento, F.A., Jaegger R.C., Roddrigues A.R. \& Souz, L.O., 2002, abstract no. Th PeF 8037, International Conference on AIDS, Barcelona, Spain, 2-12th, 14th July.

Spearman, M.S. \& Bolden, J.A., 2005, 'Identification of factors that reduce rates of detection of HIV/AIDS among women 50 years and older', Journal of African American Studies 9(2), 51-59. http://dx.doi.org/10.1007/s12111-005-1022-8

Ssengonzi, R., 2007, 'The plight of older persons as caregivers to people infected/ affected by HIV/AIDS: Evidence from Uganda', Journal of Cross Cultural Gerontology 22, 339-358. http://dx.doi.org/10.1007/s10823-007-9043-5, PMid:17694427

Ssengozi, R., 2009, 'The impact of HIV/AIDS on the living arrangements and well-being of the elderly caregivers in Uganda', AIDS CARE 21(3), 309-314. http://dx.doi. org/10.1080/09540120802183461, PMid:18780191

UNAIDS \& UNICEF, 2004, Children on the Brink 2004: A joint report of New Orphan Estimates and Framework for Action, UNAIDS, New York.

Van Dullemen, C., 2006, 'Older people in Africa: New Engines to Society?', NWSA Journal 18(1), 99-105. http://dx.doi.org/10.1080/09540120802183461, PMid:18780191

Waysdorf, S.L., 2002, 'The aging of AIDS epidemic: Emerging legal and public health issues for elderly persons living with HIV/AIDS', The Elderly Law Journal 10(1), 47-51. PMid:15586460

Zimmer, Z. \& Dayton, J., 2005, 'Older adults in sub-Saharan Africa living with children and grandchildren', Population Studies 59 (3): 295-312. http://dx.doi. org/10.1080/00324720500212255, PMid:16249151 